\title{
Detection and Phenotypic Characterization of Adult Neurogenesis
}

\author{
H. Georg Kuhn ${ }^{1}$, Amelia J. Eisch ${ }^{2}$, Kirsty Spalding ${ }^{3}$, and Daniel A. Peterson ${ }^{4}$ \\ ${ }^{1}$ Institute for Neuroscience and Physiology, University of Gothenburg, Gothenburg, SE-405 30, Sweden \\ ${ }^{2}$ Department of Psychiatry, University of Texas Southwestern Medical Center, Dallas, Texas 75390-9070 \\ ${ }^{3}$ Department of Cell and Molecular Biology, Karolinska Institute, Stockholm SE-171 77, Sweden \\ ${ }^{4}$ Center for Stem Cell and Regenerative Medicine, Rosalind Franklin University of Medicine and Science, \\ North Chicago, Illinois 60064 \\ Correspondence: georg.kuhn@neuro.gu.se
}

Studies of adult neurogenesis have greatly expanded in the last decade, largely as a result of improved tools for detecting and quantifying neurogenesis. In this review, we summarize and critically evaluate detection methods for neurogenesis in mammalian and human brain tissue. Besides thymidine analog labeling, cell-cycle markers are discussed, as well as cell stage and lineage commitment markers. Use of these histological tools is critically evaluated in terms of their strengths and limitations, as well as possible artifacts. Finally, we discuss the method of radiocarbon dating for determining cell and tissue turnover in humans.

$\mathrm{D}$ etection of neurogenesis in vivo requires the ability to image at a cellular resolution, which currently precludes noninvasive imaging approaches, such as magnetic resonance imaging (MRI). In vivo microscopy, using deeply penetrating UV illumination with multiphoton microscopy, or by the recently available endoscopic confocal microscopy, may provide new opportunities for longitudinal studies of neurogenesis in the living animal with single-cell resolution. These newer microscopy approaches are particularly compelling when coupled with transgenic mice expressing phenotype-specific fluorescent reporter genes. Additionally, an advanced method using ${ }^{14} \mathrm{C}$ carbon dating of postmortem DNA from specific cell populations of the brain revealed insights into adult human neurogenesis. Nevertheless, at present, the pre- dominant approach for studying neurogenesis relies on traditional histological methods of fixation, production of tissue sections, staining, and microscopic analysis.

This review discusses methodological considerations for detection of neurogenesis in the adult brain according to our current state of knowledge. This will include the use of exogenous or endogenous markers of cell cycle, as well as phenotype markers that contribute to resolving stages of neuronal lineage commitment. The accurate analysis of cell phenotype will be discussed, including suggestions for accurate detection and reliable quantification of cell numbers. Finally, we will present the newly developed ${ }^{14} \mathrm{C}$ carbon dating of nuclear DNA for quantitative analysis of neurogenesis in human tissue.

Editors: Fred H. Gage, Gerd Kempermann, and Hongjun Song

Additional Perspectives on Neurogenesis available at www.cshperspectives.org

Copyright (C) 2016 Cold Spring Harbor Laboratory Press; all rights reserved; doi: 10.1101/cshperspect.a025981

Cite this article as Cold Spring Harb Perspect Biol 2016;8:a025981 
H.G. Kuhn et al.

\section{CELL-CYCLE PROGRESSION}

Thymidine Analogs as Exogenous Markers of DNA Replication

The ability to label a cohort of dividing cells has been useful in verifying the existence of adult neurogenesis and in monitoring changes in neurogenesis under different conditions. The original approach was to use autoradiography to detect incorporation of ${ }^{3} \mathrm{H}$-thymidine into the nuclear DNA during the $\mathrm{S}$ phase of the cell cycle. However, this detection was ambiguous, as ${ }^{3} \mathrm{H}$-thymidine-induced silver grain deposits and immunoperoxidase labels of phenotypic markers were in different focal planes. The use of the thymidine analog bromodeoxyuridine (BrdU) allowed researchers to overcome this problem as its presence in the nucleus was detected by immunohistochemistry rather than autoradiography. This permitted single labeling or multiple labeling with phenotypic markers detected by brightfield or fluorescence microscopy, and use of thicker sections suitable for design-based stereological quantification of BrdU-immunoreactive cells. Thus, administration of thymidine analogs, rather than thymidine, is now used in most in vivo neurogenesis studies. A summary of study design considerations is presented in Table 1.

When given as a pulse and examined soon after administration (within hours), BrdU labeling indicates that the cell has entered $S$ phase. However, when given repeatedly or examined long after administration, BrdU labeling detection of progression into the $G_{2}$ phase of cell cycle or the subsequent reentry into additional cell cycles cannot be distinguished (Fig. 1B). To achieve this degree of temporal discrimination, the examination of endogenous cell-cycle proteins is recommended as discussed below. Commonly, a combination of BrdU and endogenous cell-cycle markers has been adopted to calculate cell-cycle kinetics. However, the question of cell-cycle reentry can also be addressed by the use of sequential administration of multiple halogenated thymidine analogs. Replacement of the bromo group with iodo or chloro groups results in thymidine analogs that behave similarly to BrdU, but whose incorporation can be discriminated immunohistochemically (Vega and Peterson 2005). Thus, by timing the delivery of each analog, it is possible to address questions of cell-cycle kinetics, particularly, the frequency to reenter cell cycle in a given cell population (Thomas et al. 2007; see also Fig. 3) or to label separate populations of cells that divide at different times. However, it is critical for the administration of the halogenated thymidine analogs to be given at an equimolar ratio for valid comparisons to be made (Vega and Peterson 2005).

\section{Possible Artifacts to Thymidine Analog Incorporation}

Thymidine analog antibodies have been generated from a variety of species as monoclonal and polyclonal antibodies. Binding of the antibody to labeled DNA requires denaturation of the DNA to remove histones, reduce tertiary DNA structures, or even generate single-stranded DNA. Denaturation is usually performed by exposing cells or tissue to hydrochloric acid, heat, enzymatic digestion, or a combination, depending on the specific antibody and tissue (Kass et al. 2000). Some suppliers mention in their antibody specifications a possible cross-reactivity with methylated DNA that could lead to unspecific labeling of all nuclei and, therefore, recommend specific pretreatment.

Several conditions can create false-positive signals, producing sporadic reports of neurogenesis in novel regions or in response to injury, which show the need for careful controls in tissue preparation (Grassi Zucconi and Giuditta 2002; Rakic 2002; Kuan et al. 2004). The specificity of primary antibodies to BrdU-labeled DNA should be determined for each tissue through the use of a 2-h BrdU pulse-chase interval for labeling with the results compared with coexpression with endogenous cell-cycle markers for confirmation (Fig. 1). Through these tests, widespread unspecific labeling could be unmasked.

Incorporation of thymidine analogs also can occur during DNA repair, leading to concerns that some observations of cell proliferation could be a result of this modest incorporation rather than transition through $S$ phase. Clearly, 
Detection and Characterization of Neurogenesis

Table 1. Suggested parameters for in vivo neurogenesis studies using thymidine analogs to detect newly generated cells

\begin{tabular}{|c|c|c|c|c|}
\hline & $\begin{array}{c}\text { Thymidine analog } \\
\text { injection } \\
\text { frequency }\end{array}$ & $\begin{array}{l}\text { Postinjection } \\
\text { examination } \\
\text { interval }\end{array}$ & Cells identified & $\begin{array}{c}\text { Key } \\
\text { considerations }\end{array}$ \\
\hline \multirow[t]{2}{*}{ Proliferation } & $\begin{array}{l}50 \mathrm{mg} / \mathrm{kg} \text { BrdU } \\
\text { or equimolar } \\
\text { equivalent } \\
\text { of IdU or CldU }\end{array}$ & $\begin{array}{c}2 \mathrm{~h} \text { after last } \\
\text { injection }\end{array}$ & $\begin{array}{l}\text { Cohort of } \\
\text { proliferating } \\
\text { cells }\end{array}$ & $\begin{array}{l}\text { Validate against false- } \\
\text { positive artifacts as } \\
\text { described in text }\end{array}$ \\
\hline & $\begin{array}{l}1-3 \text { injections at } \\
2-\mathrm{h} \text { intervals }\end{array}$ & & & $\begin{array}{l}\text { Conditions of low } \\
\text { proliferation (such as } \\
\text { aging) may require } \\
\text { more injections to } \\
\text { establish a detectable } \\
\text { cohort }\end{array}$ \\
\hline \multirow[t]{2}{*}{$\begin{array}{r}\text { Cell-cycle } \\
\text { reentry }\end{array}$} & $\begin{array}{l}1-3 \text { injections of } \\
\text { IdU at } 2-h \\
\text { intervals, then: }\end{array}$ & $\begin{array}{l}\text { Variable interval } \\
\text { between } \\
\text { analogs } \\
\text { based on } \\
\text { study } \\
\text { question }\end{array}$ & $\begin{array}{l}\text { Subpopulation of } \\
\text { rapidly dividing } \\
\text { cells }\end{array}$ & $\begin{array}{l}\text { Administration of } \\
\text { analogs must be } \\
\text { equimolar to allow } \\
\text { comparison between } \\
\text { each cohort of } \\
\text { proliferating cells }\end{array}$ \\
\hline & $\begin{array}{l}\text { 1-3 injections of } \\
\text { CldU at } 2-\mathrm{h} \\
\text { intervals }\end{array}$ & $\begin{array}{l}2 \mathrm{~h} \text { after last } \\
\text { injection }\end{array}$ & & $\begin{array}{l}\text { Order of analog } \\
\text { administration is } \\
\text { unimportant and } \\
\text { could be reversed to } \\
\text { CldU first, then IdU } \\
\text { Interval between } \\
\text { delivery provides } \\
\text { an index of cycle } \\
\text { length }\end{array}$ \\
\hline \multirow[t]{2}{*}{$\begin{array}{l}\text { Fate } \\
\text { specification }\end{array}$} & $\begin{array}{r}50 \mathrm{mg} / \mathrm{kg} \mathrm{BrdU} \\
\text { or equimolar } \\
\text { equivalent of } \\
\text { IdU or CldU }\end{array}$ & $\begin{array}{l}\text { Approximately } \\
3-10 \text { days } \\
\text { after last } \\
\text { injection }\end{array}$ & $\begin{array}{l}\text { Recently generated } \\
\text { cells coexpressing } \\
\text { early lineage } \\
\text { markers }\end{array}$ & $\begin{array}{l}\text { Validate that detection } \\
\text { is in appropriate cell } \\
\text { compartments for } \\
\text { confirming true } \\
\text { coexpression as } \\
\text { described in text }\end{array}$ \\
\hline & $\begin{array}{l}1-3 \text { injections } \\
\text { at } 2-\mathrm{h} \\
\text { intervals }\end{array}$ & & & $\begin{array}{l}\text { Lineage commitment } \\
\text { may produce a } \\
\text { transient overlap } \\
\text { of phenotypic } \\
\text { markers }\end{array}$ \\
\hline \multirow[t]{2}{*}{$\begin{array}{l}\text { Neuronal } \\
\text { maturation }\end{array}$} & $\begin{array}{l}50 \mathrm{mg} / \mathrm{kg} \mathrm{BrdU} \text { or } \\
\text { equimolar } \\
\text { equivalent of } \\
\text { IdU or CldU }\end{array}$ & $\begin{array}{l}2-4 \text { wk after } \\
\text { last injection }\end{array}$ & $\begin{array}{l}\text { Newly generated } \\
\text { cells differentiating } \\
\text { into phenotypically } \\
\text { mature neurons }\end{array}$ & $\begin{array}{l}\text { Cells observed may } \\
\text { express various } \\
\text { differentiation } \\
\text { markers, requiring } \\
\text { multiple labeling } \\
\text { approaches }\end{array}$ \\
\hline & $\begin{array}{l}1-3 \text { injections at } \\
2-\mathrm{h} \text { intervals }\end{array}$ & & & $\begin{array}{l}\text { Cells observed reflect } \\
\text { the net result of } \\
\text { continued proliferation } \\
\text { following labeling } \\
\text { and cell loss }\end{array}$ \\
\hline
\end{tabular}

Continued 
H.G. Kuhn et al.

Table 1. Continued

\begin{tabular}{|c|c|c|c|c|}
\hline & $\begin{array}{c}\text { Thymidine analog } \\
\text { injection } \\
\text { frequency }\end{array}$ & $\begin{array}{l}\text { Postinjection } \\
\text { examination } \\
\text { interval }\end{array}$ & Cells identified & $\begin{array}{c}\text { Key } \\
\text { considerations }\end{array}$ \\
\hline \multirow[t]{2}{*}{ Survival } & $\begin{array}{r}50 \mathrm{mg} / \mathrm{kg} \text { BrdU } \\
\text { or equimolar } \\
\text { equivalent of } \\
\text { IdU or CldU }\end{array}$ & $\begin{array}{l}\text { Varies } \\
\text { depending } \\
\text { on study } \\
\text { question }\end{array}$ & $\begin{array}{l}\text { Intervals of }<10 \\
\text { days address short- } \\
\text { and long-term } \\
\text { survival }\end{array}$ & $\begin{array}{l}\text { Study could combine } \\
\text { IdU/CldU delivery } \\
\text { to provide baseline } \\
\text { data for comparison } \\
\text { to proliferation } \\
\text { within the same } \\
\text { animal under the } \\
\text { same conditions }\end{array}$ \\
\hline & $\begin{array}{l}1-3 \text { injections at } \\
2-\mathrm{h} \text { intervals }\end{array}$ & & $\begin{array}{l}\text { Intervals }>30 \text { days } \\
\text { assess integration }\end{array}$ & $\begin{array}{l}\text { Assessment of } \\
\text { integration should be } \\
\text { combined with } \\
\text { a functional readout }\end{array}$ \\
\hline \multirow[t]{2}{*}{$\begin{array}{l}\text { Rare/valuable } \\
\text { subjects }\end{array}$} & $\begin{array}{l}1-3 \text { injections of } \\
\text { IdU at } 2-\mathrm{h} \\
\text { intervals, then: }\end{array}$ & $\begin{array}{l}\text { 2-4 wk after } \\
\text { IdU } \\
\text { injection } \\
\text { (first cohort) }\end{array}$ & $\begin{array}{l}\text { Differentiation from } \\
\text { cells in the } \\
\text { first cohort }\end{array}$ & $\begin{array}{l}\text { Permits efficient use of } \\
\text { rare or valuable } \\
\text { subjects for } \\
\text { measuring both } \\
\text { proliferation and } \\
\text { differentiation }\end{array}$ \\
\hline & $\begin{array}{l}1-3 \text { injections } \\
\text { of ldU at } \\
\text { 2-h intervals }\end{array}$ & $\begin{array}{l}2 \mathrm{~h} \text { after CldU } \\
\text { injection } \\
\text { (second } \\
\text { cohort) }\end{array}$ & $\begin{array}{l}\text { Proliferation from } \\
\text { cells in the } \\
\text { second cohort }\end{array}$ & $\begin{array}{l}\text { Permits use of same } \\
\text { animal for increased } \\
\text { statistical power }\end{array}$ \\
\hline
\end{tabular}

BrdU, Bromodeoxyuridine; IdU, iododeoxyuridine; CldU, chlorodeoxyuridine.

complete replication of the genome during cell division will incorporate thymidine analogs to a much higher extent than limited DNA repair (Cooper-Kuhn and Kuhn 2002). Nevertheless, it was suggested that immunohistology could also detect incorporation from DNA repair (Kuan et al. 2004). Whether this occurs at detectable levels depends largely on the extent of DNA damage and BrdU dose/availability. Cells that undergo extensive DNA repair can reside in lesioned tissue, for example, after radiation or ischemia. Damaged cells can also up-regulate cell-cycle markers and even undergo aberrant cell-cycle entry, making the distinction between apoptosis and cell-cycle entry even more difficult (Busser et al. 1998; Yang et al. 2001). Although a more recent study suggests that mistaken apoptosis may not be a great concern in the adult brain (Bauer and Patterson 2005), investigators should still use caution in interpretation. The use of a lower dose of thymidine analog (50 mg/ $\mathrm{kg}$ for BrdU or equivalent) is recommended to reduce the probability of detecting lower levels of non-S-phase thymidine analog incorporation, particularly, as these lower doses are equally effective at detecting proliferation (Burns and Kuan 2005).

\section{Ethynyl-Deoxyuridine}

5-ethynyl-2'-deoxyuridine (EdU) represents an alternative thymidine analog, in which the terminal methyl group is replaced with an alkyne group, which allows detection using so-called "click chemistry" instead of antibody binding (for details, see Buck et al. 2008; Zeng et al. 2010). The advantage of EdU labeling over conventional BrdU detection is that no DNA denaturation step is necessary, thereby preserving other epitopes and increasing reproducibility.

\section{Endogenous Cell-Cycle Proteins}

Although thymidine analog incorporation has the benefit of providing a temporal signature for 
A The cell cycle

\begin{tabular}{|l|l|l|l|}
\hline & \multicolumn{3}{|l|}{} \\
\hline $\mathrm{G}_{1}$ & $\mathrm{~S}$ & $\mathrm{G}_{2}$ & $\mathrm{M}$ \\
\hline
\end{tabular}

B Exogenous DNA replication markers

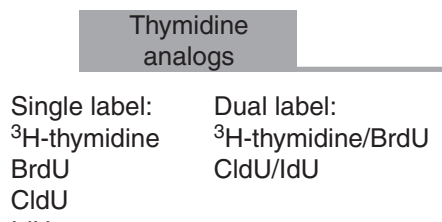

IdU

C Endogenous cellcycle proteins

$\mathrm{pHisH3}$

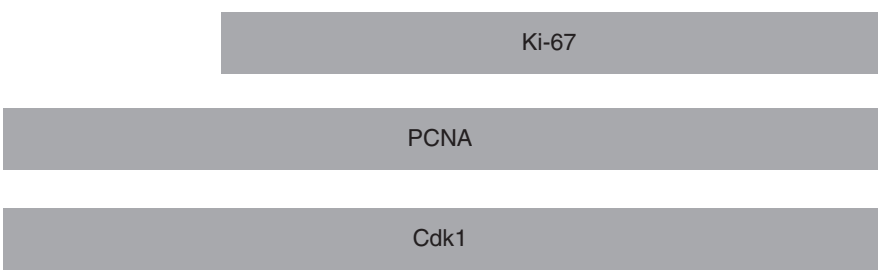

Figure 1. Detection of neurogenic proliferation. $(A)$ The mitotic cell cycle consists of the regulated transition of a cell through the sequential phases of $G_{1}, S, G_{2}$, and $M$ from which the cell can remain postmitotic or reenter the cell cycle again. (B) DNA replication occurs during $S$ phase (synthesis), and this essential step of the cell cycle can be detected by the availability of thymidine analogs that are incorporated during DNA replication and can be, subsequently, detected by immunocytochemistry. Thymidine analogs allow birthdating as they define the time of incorporation, but they do not discriminate subsequent phases of the cell cycle (illustrated by the tail extending on into $G_{2}$ and $\left.M\right)$. DNA replication can be probed once more to determine whether a labeled cell has again reentered cell-cycle pairing of ${ }^{3} \mathrm{H}$-thymidine and bromodeoxyuridine (BrdU) or chlorodeoxyuridine (CldU) and iododeoxyuridine (IdU). (C) Endogenous cell-cycle proteins are expressed at different stages of cell-cycle progression and their expression offers a tool to examine regulation of cell-cycle progression. Some of these, such as Cdk1 and proliferating cell nuclear antigen (PCNA), are broadly expressed throughout the cell cycle and thus provide low temporal resolution about specific cell-cycle progression. Ki67 closely corresponds to thymidine analog detection as it is expressed both during $S$ phase and through the remainder of the cell cycle. More specific temporal resolution is offered by phosphohistone $\mathrm{H} 3$ ( $\mathrm{pHisH} 3$ ), which is only expressed following $\mathrm{S}$ phase.

DNA replication, as noted above, there are also drawbacks of using this approach. An additional concern is that the incorporation of an analog like BrdU into the new strand of DNA may negatively influence cell-cycle kinetics, DNA transcription, or, ultimately, cell viability. This is, particularly, a concern during early life when proliferation is high, but may also be a concern in the adult if thymidine analogs are given in a way that targets the same cells over a period of time (e.g., provided in the drinking water or one injection each day at the same time over many days). Also, the thymidine analog may dilute after each cell division, making data interpretation challenging.

Because of these and other drawbacks (Eisch and Mandyam 2004), there is an increasing use of endogenous cell-cycle proteins to label cells engaged in the process of cell cycle at the time of tissue harvest. As illustrated in Figure 1, a variety of cell-cycle proteins have been used to detect separate phases of cell-cycle progression (see Eisch and Mandyam 2004, 2007 for comprehensive reviews of endogenous proteins in adult neurogenesis). Quantification of cells expressing cell-cycle proteins provides a valuable tool for 
H.G. Kuhn et al.

examining how changes to the microenvironmental niche might specifically regulate cell proliferation. Also, the differential expression of key cell-cycle protein precursors of different lineages has also been useful in understanding the different kinetics underlying, for example, neural versus oligodendrocytic precursors (Matsumoto et al. 2011). Recently, endogenous cell-cycle proteins have also been found in cells in certain stages of adult neurogenesis development, for example, p2 $7^{\text {kip } 1}$ in neural stem cells (Andreu et al. 2014) and cyclin D2 in progenitor cells (Kowalczyk et al. 2004). Combination of exogenous thymidine analog administration and endogenous cell-cycle protein detection can corroborate the findings with exogenous markers and provide additional details about cell-cycle kinetics (Lagace et al. 2010; Zhang et al. 2013).

Labeling for endogenous cell-cycle proteins has an advantage in that only, currently, cycling cells are detected, whereas with thymidine analog delivery, the event of DNA replication obscures subsequent discrimination of cell-cycle activity (unless temporal separation of chlorodeoxyuridine [CldU] and iododeoxyuridine [IdU] probes are used, as discussed above). This benefit of labeling endogenous cell-cycle proteins has been applied to normal and pathological states, such as human depression (reviewed in Patricio et al. 2013), and may afford researchers a novel approach to understanding the regulation of neurogenesis from a cell-cycle perspective. Another practical advantage of endogenous protein detection is in studies, in which it is not feasible to deliver thymidine analogs, such as in use of wild animal populations and human postmortem tissue. However, caution must be exercised in equating thymidine analog studies with use of endogenous protein detection because of the fact that the cell-cycle proteins reveal a wider population of cells activated for cell cycle, not all of which may necessarily proceed through DNA replication if held up at an upstream checkpoint.

\section{Lineage Tracking by Retroviral Vectors}

Retroviral vectors specifically infect dividing cells, and this property has been used with great suc- cess for in vivo delivery of transgenes to proliferating cells in neurogenic niches (for more details, see Enikolopov et al. 2015). Use of fluorescent reporter genes, such as green fluorescent protein (GFP), has revealed the ensuing morphological development and distribution of newly generated cells and proven to be a useful lineage marker for studies of subsequent lineage commitment. The filling of cells with GFP has enabled specific studies of functional connections of newly generated cells and allowed their identification in slice preparations for studying their electrophysiological maturation and integration (van Praag et al. 2002; Laplagne et al. 2006). Despite the usefulness of retroviral-mediated delivery of fluorescent reporter genes for lineage marker studies, caution should be used as transfer of fluorescent protein to a postmitotic neuron has been reported following infection of proliferating microglial cells (Ackman et al. 2006).

\section{LINEAGE COMMITMENT}

As in brain development, newly generated cells in the adult brain progress through a series of lineage commitment stages before the adoption of mature phenotype markers and evidence of function (Kempermann et al. 2004). The markers that are presently available are not strictly sequential in their expression, but overlap to a varying degree as lineage commitment proceeds (Fig. 2). Although the expression of recognized lineage commitment markers provides a useful construct for our understanding of the process, it is obvious that their expression pattern reflects molecular regulatory events that we are only beginning to understand. Useful new tools have recently been reported using transgenic mice, in which fluorescent reporter genes are under the control of promoters relevant for neurogenic progression, such as nestin, glial fibrillary acidic protein (GFAP), Olig2, and doublecortin (DCX) (for details, see Enikolopov et al. 2015).

\section{Markers of Neural Stem Cells}

The study of early events in stem cell biology, such as self-renewal and lineage commitment, 
A Progression of adult neurogenesis

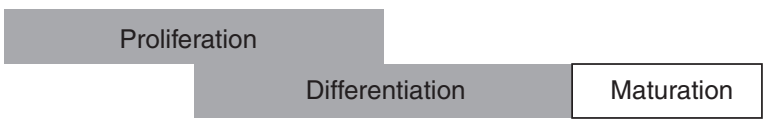

B Stem/progenitor markers

GFAP, Sox2

Nestin

C Neuronal lineage markers

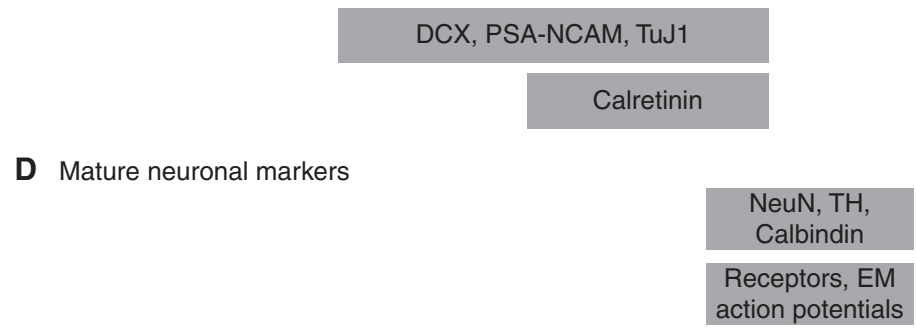

Figure 2. Detection of progression through lineage commitment. (A) Neurogenesis occurs by progression through sequential phases of "proliferation" to expand the population of neural progenitor cells, "differentiation" as these cells acquire lineage commitment and migrate to their final location, and "maturation" as the newly generated cells become structurally and functionally integrated. Initially thought to proceed in a strictly sequential fashion, it is now understood that these phases may overlap. (B) A schematic representation of proliferation identifies markers of stem/progenitor cells that are proliferative and whose expression may be confined to early periods of proliferation (GFAP [ glial fibrillary acidic protein] and Sox2) or extend further into the overlapping period with differentiation (nestin). (C) With increasing lineage commitment, newly generated cells begin to express characteristic markers of neuronal commitment, some of which begin expression despite the fact that the cell has not yet terminally exited cell cycle. $(D)$ Newly generated cells that survive this process ultimately express phenotypic markers and adopt functional characteristics of mature neurons. DCX, Doublecortin; PSA-NCAM, polysialylated neuronal-cell-adhesion molecule; NeuN, neuronal nuclei; TH, tyrosine hydroxylase; EC, entorhinal cortex.

requires the ability to detect these stem cells with suitable markers. However, for the purpose of specifically detecting neurogenesis, these markers are of limited value because they can only give an indication whether a region is, in principle, able to generate new neurons. Furthermore, the multipotent character of stem cells makes it unclear to predict to what extent neuronal differentiation will be achieved and, as in development, the "neural stem cell" is likely not a homogeneous population but a heterogeneous one (DeCarolis et al. 2013). Therefore, currently, there is no single marker that is definitive for neural stem cells. The most widely used marker, nestin, is indicative of early neuroectodermal commitment, but can also be detected in vascular structures. The best practice for identifying early markers of neural stem cells relies on a combination of otherwise more ubiquitous markers, along with consideration of immunoreactive cell location and morphology. For example, radial glial-like cells in the subgranular zone expressing GFAP and nestin, GFAP and Sox-2 or Pax-6, GFAP and brain lipid-binding protein (BLBP), or ApoE and BLBP appear to label multipotent cells (Stoykova and Gruss 1994; Komitova and Eriksson 2004; Nacher et al. 2005; Baer et al. 2007; Yang et al. 2011). In fact, these combinations reflect a subset of radial glial-like astrocytes in both the subgranular and subventricular zone (AlvarezBuylla et al. 2002). As most of these markers 
H.G. Kuhn et al.

individually label populations of astrocytes, and as radial glial cells act as neuronal progenitors during embryonic development (Malatesta et al. 2000, 2003), this underscores the close, yet incompletely understood relationship between astrocytes and neural stem cells.

\section{Early Markers of Neuronal Lineage Commitment}

Ideally, neuronal lineage commitment markers need to be transiently expressed only in the neuronally committed cell population, without expression in mature neurons or other brain cell types and without reexpression in neurons under conditions of neuronal injury or regeneration. When sufficiently validated, such endogenous markers could replace BrdU labeling for detecting neurogenesis, especially under conditions that preclude BrdU delivery, such as human tissue. Several such markers have been described in recent years.

The T-domain transcription factor Tbr2 is specifically expressed in intermediate-stage progenitor cells (Type $2 \mathrm{~b}$ cells) of the dentate gyrus and in transit amplifying cells (type C cells) of the subventricular zone. BrdU and PCNA labeling has shown that Tbr2-positive cells are highly proliferative (Hodge et al. 2008). In Tbr2-knockout mice, type $2 \mathrm{~b}$ cells are depleted although neural-stem-cell proliferation is increased and, as a consequence, neuronal differentiation of the progenitor cells is halted. Tbr2 appears to promote lineage progression from neural stem cell to neuronal-specified progenitor cell, in part, by repression of Sox2, which supports multipotent neural-stem-cell maintenance (Hodge et al. 2012).

DCX, a microtubule-associated protein, is currently most widely used as it has been shown to be transiently expressed in neuronal progenitor cells and immature neurons (Brown et al. 2003; Rao and Shetty 2004; Couillard-Despres et al. 2005). However, reports indicate ectopic expression in neocortical neurons and low-level expression in NG2-positive cells (presumptive glial progenitors), which caution against the use of DCX to determine neurogenesis in brain regions not confirmed by other methods (Nacher et al. 2001). The polysialylated form (PSANCAM) of the neural-cell-adhesion molecule (NCAM) and TOAD-64 (also known as also known as TUC-4 and CRMP-4) are other examples. Similar to DCX, transient expression patterns allow labeling of neuronal progenitor cells; however, reports on expression of PSA-NCAM in glial cells and plasticity of mature neurons make these markers less specific for detection of neurogenesis (Nacher et al. 2000; Seki 2002; Nguyen et al. 2003; Bonfanti 2006). Another neuronal cytoskeletal protein, $\beta$ III-tubulin, is expressed relatively early after neuronal commitment. However, $\beta$ III-tubulin is also reported to be expressed in a large number of mature neurons, and the transient expression character is thus unclear. When used in combination with birthdating by thymidine labeling, most of these early neuronal lineage commitment markers can be reliably used to define early neuronal maturation in studies of adult neurogenesis.

\section{Markers of Maturing Neurons}

Once progenitor cells reach maturity, they will begin expressing neuronal markers, such as neurofilaments, neuronal nuclei (NeuN), calcium-binding proteins, and neurotransmitters. There are some useful region-specific markers of maturity as well. For example, the transcription factor Prox 1 almost exclusively is expressed by dentate gyrus mature neurons (Pleasure et al. 2000), making it a specific marker of maturation for adult-generated hippocampal neurons. NeuN and neurofilament can be considered as panneuronal markers; however, NeuN is absent from a few neuronal populations. Fortunately, only one of these cell types, olfactory periglomerular neurons, is generated in adulthood (Mullen et al. 1992; Winner et al. 2002). Calcium-binding proteins, neurotransmitter enzymes, and neurotransmitters are produced by maturing neurons at the time when the cells become electrophysiologically active. These molecules are specific to subclasses of neurons and, together with BrdU birthdating, they allow quantification of new neurons. The use of retroviral labeling has also provided a means to 
confirm the ultrastructural phenotype of new neurons by virtue of cell filling, enabling the identification of dendritic processes bearing mature synapses. Similarly, this technique has been used to validate the electrophysiological maturation of new neurons (van Praag et al. 2002; Laplagne et al. 2006).

\section{DETECTION OF MARKER COEXPRESSION}

\section{Multiple Labeling Approaches}

Detection of proliferating cells using exogenous thymidine analog administration or endogenous cell-cycle proteins can provide useful information about quantitative changes in proliferative activity when detected using a singlelabel immunoperoxidase staining. To extract the most information about the specific subpopulations that may be represented within the detected population, it is necessary to use multiple immunofluorescence labeling, which has become the approach of choice because of the ability to separately excite fluorophores and discriminate their emission based on spectral properties. Depending on the properties of the antibodies or dyes available and suitable instrumentation, investigators can image three to four colors for analysis. In addition, immunofluorescence can be combined with endogenous expression of fluorescent reporter genes in transgenic mice or as a result of viral reporter labeling (Fig. 3).

\section{Determination of Coexpression in Three Dimensions}

Fluorescence microscopy, particularly using confocal microscopy, facilitates the collection of expression data in three-dimensional stacks of images to provide evidence for coexpression in distinct cell compartments. The importance of using exacting standards for identifying coexpression is well illustrated by early reports in the field of adult neurogenesis mistakenly reporting its occurrence in the cerebral cortex, when actually two closely apposed cells gave the appearance of the BrdU label in mature cortical neurons (Fig. 4). Largely as a result of these missteps, evidence for colocalization now requires well-documented three-dimensional colocalization (Kornack and Rakic 2001; Bhardwaj et al. 2006a).

\section{Artifacts in Fluorescence Detection}

Despite the advantages of fluorescence for the detection of neurogenesis, artifacts need to be considered that have the potential for misidentification and misinterpretation of neurogenesis. The light emission from one fluorophore or dye may contribute a signal to another detection channel as a result of its emission spectral profile, which can overlap with the emission profile of the second fluorophore. This phenomenon is commonly called bleed-through or channel cross talk and can result in a falsepositive identification of coexpression. Bleedthrough is easily controlled for by choosing fluorophores or dyes with narrow emission spectra and always using sequential excitation and collection of each signal rather than relying on simultaneous collection of all signals. Good microscopy practice dictates that the operator should validate the specificity of each signal being detected and checking in other detection channels for the possibility of bleed-through (Table 2).

Autofluorescence, especially in aging and primate tissue, is another serious artifact that can produce interpretation errors. The natural accumulation of unprocessed cellular debris produces a broad emission spectrum when excited by a wide range of excitation wavelengths, with lower excitation wavelengths producing stronger emission. Various approaches have been proposed to quench endogenous autofluorescence before tissue staining, however, with only limited success. The best practice for imaging aging, primate or human tissue or tissue following experimental injury, in which autofluorescence may be encountered, is to evaluate the extent of emission seen in all channels following excitation with a low wavelength (Table 2). If structures are encountered with relatively equal intensity and shape over multiple detection channels, these should be regarded as possible autofluorescence. 
H.G. Kuhn et al.
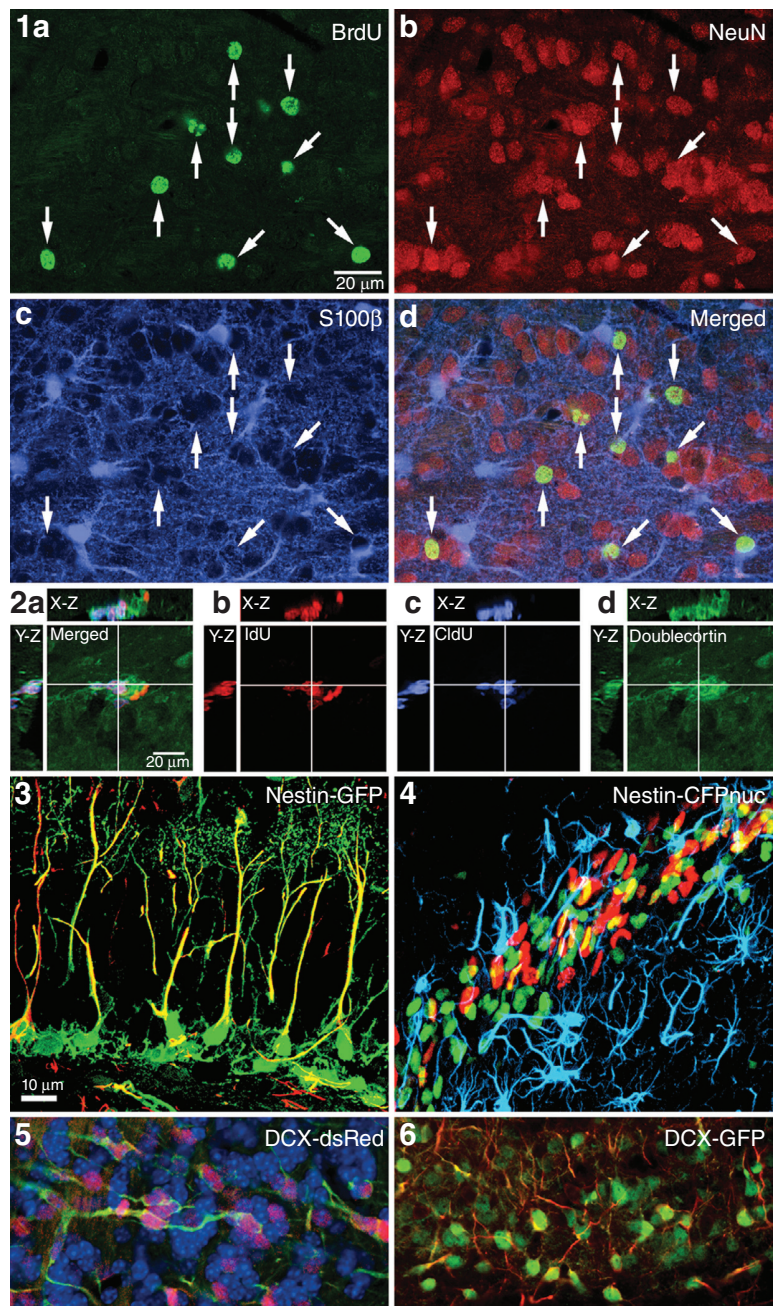

Figure 3. Detection of neurogenic markers. Detection of neurogenesis is commonly achieved by immunohistochemical detection of newly generated cells labeled with the thymidine analog bromodeoxyuridine (BrdU) (1a) assessed with their coexpression of mature neuronal markers, such as neuronal nuclei (NeuN) ( $1 b)$, or mature glial markers, such as S100 $\beta$ for mature astrocytes (1c). Coexpression can be determined from the amount of signal overlap (1d). Full determination of colocalization requires discrimination of signal colocalization in three dimensions $(2 a)$, which can be illustrated by orthogonal projections of a point in space (shown as white crosshairs) with the projected side views in the $X-Z$ and $Y$ - $Z$ planes, allowing for interactive observation of signal colocalization. Merged images can then be shown separately for each signal, such as illustrated here for the dual labeling with thymidine analogs iododeoxyuridine (IdU) $(2 b)$ and chlorodeoxyuridine (CldU) (2c) shown colocalized with doublecortin (DCX) $(2 d)$. (2a-d from Vega and Peterson 2005; modified, with permission, as per agreement with Nature Publishing Group.) Transgenic mice with fluorescent reporter genes can also be used to detect adult neurogenesis. Examples include filling of nestin-expressing cells with green fluorescent protein (GFP) (3), colabled with glial fibrillary acidic protein (GFAP) (red) in the dentate gyrus or nuclear localized cyan fluorescent protein (CFP) (green) in nestin-expressing cells in the rostral migratory stream (4) colabeled with BrdU (red) and GFAP (blue). (3 and 4 appear courtesy of Drs. J. Encinas and G. Enikolopov.) Another example of transgenic reporter mice is colabeling of endogenous DCX protein by fluorescent proteins expressed under the human DCX promoter. Note the fibrillary staining of endogenous microtubule-associated DCX colabels extensively with the diffuse cytoplasmic signal of DsRed (5) and enhanced green fluorescent protein (eGFP) (6). (Images are taken from adult olfactory bulb tissue and provided courtesy of Drs. L. Aigner and S. Couillard-Despres.) 


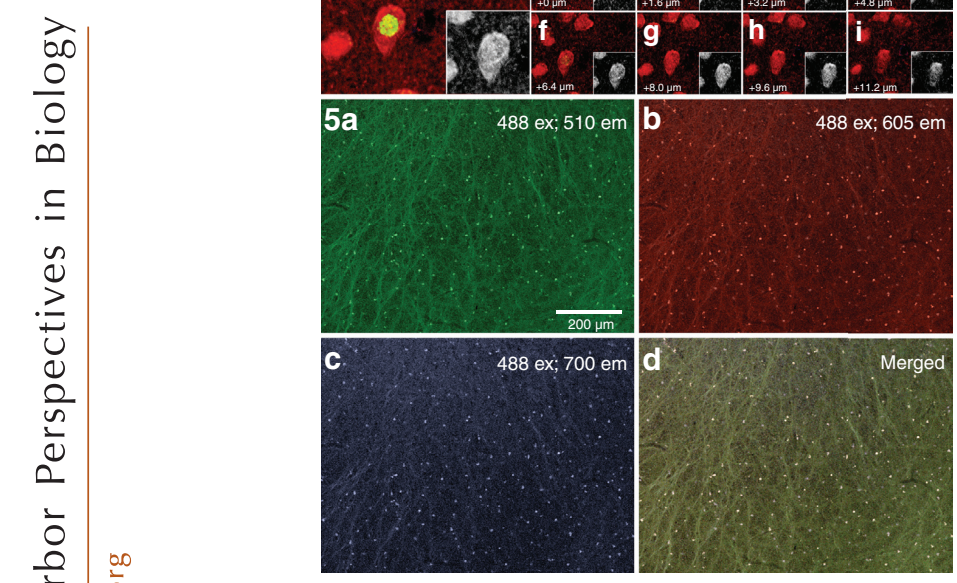

Figure 4. Potential detection artifacts. (1) Double labeling of dividing progenitor cells in the subgranular zone of the rat dentate gyrus with bromodeoxyuridine (BrdU) (green) and Ki67 (red). BrdU was injected $2 \mathrm{~h}$ before being killed. The staining indicates partial overlap of cells marked for BrdU (S phase) and Ki-67 (cell cycle). (2) False double labeling of BrdU (green) and neuronal nuclei (NeuN) (red). The yellow signal in $2 a$ can be attributed to autofluorescence of erythrocytes because the same signal is detected in the blue channel, yielding a white signal in $2 b$. (3) and (4) False double labeling of BrdU (green) and $\mathrm{NeuN}$ (red) can also be attributed to BrdU-positive satellite cells, which are in close proximity to mature neurons. $3 a$ and $3 b$ show, in side view, a satellite cell (BrdU in green), which is very closely apposed to a NeuN-positive neuron (red). Note that the cytoplasm of the neuron appears to be indented by the attached satellite cell soma (arrow in $3 b$ ). If the satellite cell and neuron are oriented along the $z$ axis, regular fluorescence microscopy will determine colabeling (see $4 a$ ), whereas $z$ stack analysis of confocal images would determine that the BrdU-positive nucleus in focus in $4 e$ does not correspond to the neuronal nucleus in focus in $4 g$. Autofluorescence is a particularly difficult artifact in aged rodent and primate tissues.
Detection and Characterization of Neurogenesis

\section{QUANTIFICATION OF NEUROGENESIS}

The neuroscience community, in recent years, has increasingly moved to using quantitative approaches, described as design-based stereology, to reduce the contribution of errors and artifacts, and to obtain a reliable estimate of the total population of cell types within anatomical structures (Peterson 1999, 2004, 2014; Schmitz and Hof 2005). The production of estimates of all the labeled cells in a structure is a much more biologically relevant parameter than estimates based on a density (area, volume, or per section), which are subject to alteration between experimental conditions. The need to produce three-dimensional stacks of confocal images to accurately assess colocalization (discussed above) only requires careful standardization in sampling parameters to be suited for using stereology (Table 3). However, the image stacks themselves must be collected in a true systematic random fashion to properly adhere to stereological principles (Peterson 2014).

There are some challenges to implementing stereology in studies of adult neurogenesis, primarily because of the low abundance of newly generated cells in some neurogenic regions (particularly, the hippocampal dentate gyrus) and in regions being assessed for response of neural stem cells to injury or other experimental perturbation. As cells in such regions are relatively infrequent and often found in clusters, there has been considerable discussion about the use of stereology in these circumstances.

Figure 4. (Continued) Unstained sections mounted and imaged directly show autofluorescence in the olfactory bulb shown by excitation illumination at $488 \mathrm{~nm}$, resulting in nonspecific emission of autofluorescing particles at $510 \mathrm{~nm}$ (green, $5 a$ ), $605 \mathrm{~nm}$ (red, 5b), and $700 \mathrm{~nm}$ (blue, 5c). Merging all channels of detection shows that the resulting combination of emission detection does not always produce the additive color of white as signal intensity differs between detection channels. The low power view shown in $5 a$ would appear similar following staining for BrdU and the false-positive autofluorescence would have to be carefully discriminated from the true BrdU-positive signal to avoid overcounting. 
H.G. Kuhn et al.

Table 2. Best practices for detecting label coexpression

Use fluorescence labeling when possible for precise discrimination of signal.

Use appropriate high numerical aperture objective lenses for the best axial resolution (i.e., the narrowest depth of field).

Use appropriate filters for specific fluorescence signal detection.

Use entire dynamic range of signal detection to avoid oversaturating the image and obscuring coexpression.

Collect a three-dimensional image stack to fully identify signal distribution within cell compartments.

Validate that image does not contain signal bleedthrough by collecting each channel with separate excitation.

Validate that apparent colocalization is not autofluorescence by examining if low wavelength excitation produces emission at longer wavelengths.

(for more details about sampling strategies, see Peterson 2014).

\section{RADIOCARBON DATING}

A recently devised strategy for measuring cell and tissue turnover in humans, unrelated to the histological methods described above, involves radiocarbon dating of genomic DNA (Spalding et al. 2005). Using this strategy, cell turnover is determined by measuring the integration of ${ }^{14} \mathrm{C}$ derived from nuclear bomb tests into genomic DNA. This strategy has been used to determine neuronal age in the adult human cortex and cerebellum (Spalding et al. 2005; Bhardwaj et al. 2006a), olfactory bulb (Bergmann et al. 2009), hippocampus (Spalding et al. 2013), and striatum (Ernst et al. 2014), as well as cardiomyocyte turnover in the adult human heart (Bergmann et al. 2009) and adipocyte turnover in adult human subcutaneous adipose tissue (Spalding et al. 2008).

Normal atmospheric levels of the radioactive isotope ${ }^{14} \mathrm{C}$ are extremely low; however, atmospheric thermonuclear-bomb testing in the late 1950s and early 1960s doubled atmospheric levels of ${ }^{14} \mathrm{C}$ (Nydal and Lovseth 1965). Above- ground nuclear bomb testing ended in 1963 (Test Ban Treaty) and, as a result, atmospheric levels of ${ }^{14} \mathrm{C}$ have been decreasing ever since (Fig. 5A,B). These levels have been measured and plotted as a function of $\Delta^{14} \mathrm{C}$ (atmospheric ${ }^{14} \mathrm{C}$ measurements corrected for isotopic fractionation and radioactive decay) and time to form what is known as a "bomb-spike" plot (Fig. $5 \mathrm{~A}, \mathrm{~B}) .{ }^{14} \mathrm{C}$ in the atmosphere reacts with oxygen and forms $\mathrm{CO}_{2}$, which enters the biotope through photosynthesis. Our consumption of plants, and animals that live off plants, results in ${ }^{14} \mathrm{C}$ levels in the human body paralleling those in the atmosphere. Most molecules in a cell are in constant flux, with the unique exception of genomic DNA, which is not exchanged after a cell has gone through its last division. Nucleotide exchange in postmitotic cells is minimal (Spalding et al. 2005). As such, the level of ${ }^{14} \mathrm{C}$ integrated into genomic DNA reflects the level in the atmosphere at any given time and can be used to retrospectively establish the birth date of cells in the human body (Spalding et al. 2005, 2008, 2013; Bhardwaj et al. 2006b; Bergmann et al. 2009).

Establishing the concentration of $14 \mathrm{C}$ in DNA is performed using high precision accel-

Table 3. Best practices for quantifying neurogenesis

Use appropriate high numerical aperture oil immersion objective lenses for the best axial resolution (i.e., the narrowest depth of field).

Validate staining exists throughout the mounted section thickness so that there is no "dead zone" in the middle devoid of staining where no cells will be counted, although they may exist there.

Use design-based stereological sampling to estimate total cell number independent from differences in region or volume between experimental and control conditions.

Determine the thickness of mounted (not cut) tissue for use in calculating results.

Use careful systematic sampling of the tissue when collecting image stacks to ensure compliance with stereological formulas.

Confocal image stacks are ready-made for stereological counting, but use guard zones and dissector probe counting rules to avoid artifacts and methodological biases. 

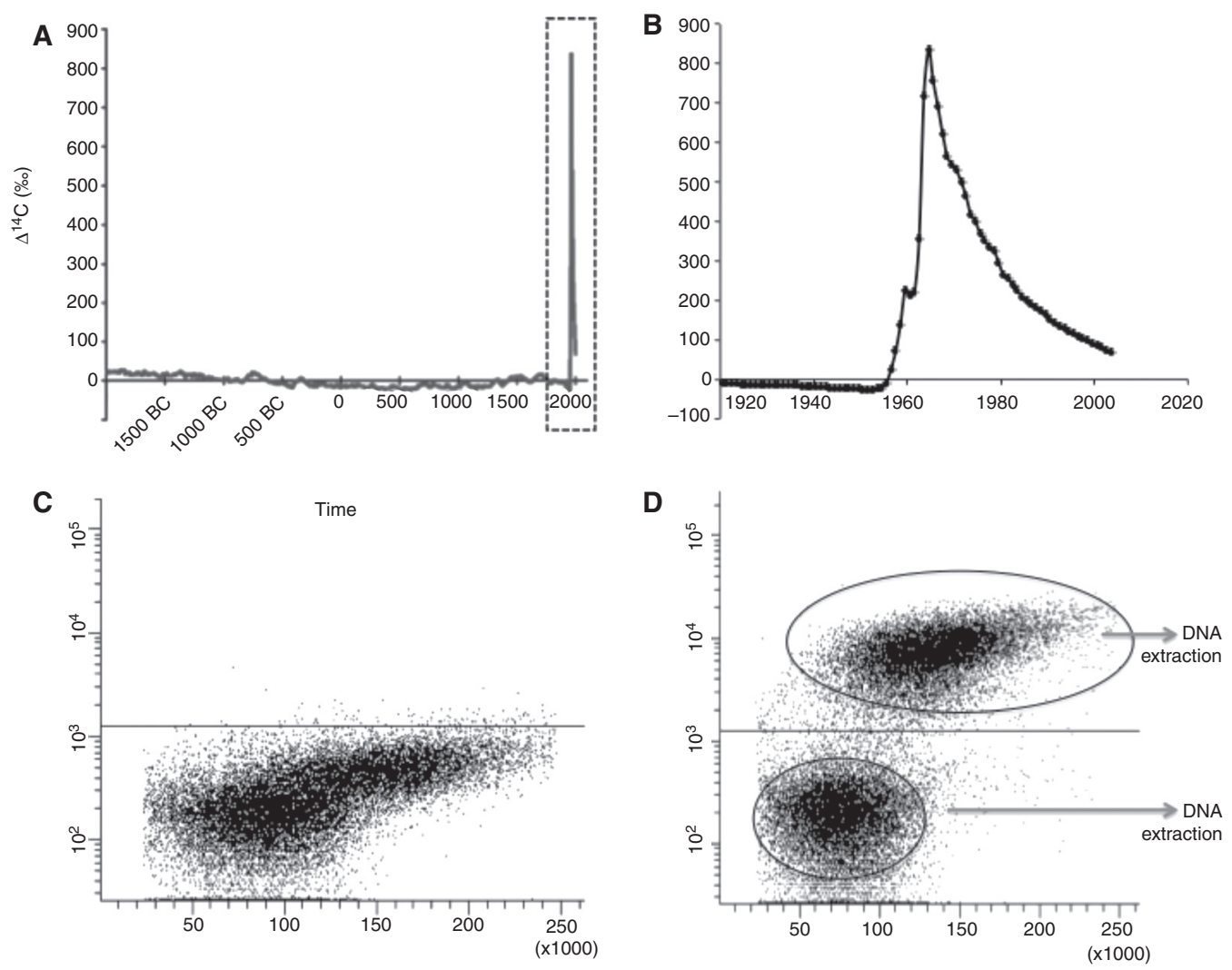

Figure 5. Detection of ${ }^{14} \mathrm{C}$ incorporation. ${ }^{14} \mathrm{C}$ levels in the atmosphere have been stable over long time periods, with the exception of a large addition of ${ }^{14} \mathrm{C}$ from 1955 to 1963 as a result of nuclear bomb tests $(A)$, forming what is known as the "bomb-spike." This bomb spike is depicted over a shorter time span in $B$, showing the sharp increase in atmospheric ${ }^{14} \mathrm{C}$ levels at the beginning of the cold war (shown as a $\Delta^{14} \mathrm{C}$ value, which gives the atmospheric ratio of ${ }^{14} \mathrm{C}$ to ${ }^{12} \mathrm{C}$ and takes into account isotopic fractionation and radioactive decay) and the subsequent decrease following the 1963 Test Ban Treaty. $(C, D)$ Isolation of neuronal and nonneuronal nuclei from the adult human cortex. Cell nuclei were isolated from the human postmortem hippocampus and incubated with an isotype control antibody $(C)$ or with an antibody against the neuron-specific epitope (neuronal nuclei $[\mathrm{NeuN}])(D)$. Neuronal and nonneuronal populations are isolated by flow cytometry and collected for DNA extraction. Fluorescence-activated cell sorting (FACS) plot depicts nuclei size on the $x$ axis (forward scatter area) and NeuN fluorescence intensity on the $y$ axis. The sorting gates for neuronal and nonneuronal nuclei are indicated.

erator mass spectrometry (AMS). Traditional AMS methods could not measure biological levels of ${ }^{14} \mathrm{C}$ (Vogel and Love 2005). However, significant advances in the sensitivity and accuracy of mass-spectrometric techniques enable present-day AMS to count the number of ${ }^{14} \mathrm{C}$ atoms in a sample to the level of parts per billion to parts per quadrillion, resolving dating periods on the order of months to years rather than hundreds or thousands of years.
Mathematical models can be used to estimate cell turnover in renewing biological systems with the age distribution of DNA estimated from the integration of radiocarbon derived from nuclear bomb testing (Spalding et al. 2008, 2013; Bergmann et al. 2009; Bernard et al. 2010). For slowly renewing tissues, this method provides a better estimate of the average age of the tissue than direct estimates from the bomb curve. Moreover, death, birth, and turnover rates can 
H.G. Kuhn et al.

be estimated. For a detailed discussion of mathematical modeling of radiocarbon data, the reader is referred to Bergmann et al. (2009), Bernard (2010), and Spalding et al. (2013).

To study neurogenesis, neurons need to be separated from all other cell types in the adult human brain. This is achieved by using antibodies to cell-type-specific nuclear epitopes and flow cytometry. Nuclei isolated from dissected brain regions are labeled with a directly conjugated nuclear-specific neuronal antibody and sorted using flow cytometry (Fig. 5C,D). NeuN (Fox3) has been extensively validated as a marker for most neuronal subsets; however, some cell types, such as mitral- and glomerularlayer cells of the olfactory bulb, are not immunoreactive to NeuN (Bergmann et al. 2012). In this case, antibodies to the RNA-binding protein $\mathrm{HuD}$, which is specific to postmitotic neurons (Barami et al. 1995), can be used to isolate NeuN-negative neurons. Because some oligodendrocytes also positively label with $\mathrm{HuD}$, the addition of an oligodendrocyte-negative sorting gate ensures neuronal specificity (i.e., $\mathrm{HuD}^{+}$, Sox $\left.10^{-}\right)$. Neuronal and nonneuronal nuclei are then collected, DNA extracted, and sent for AMS analyses.

\section{SUMMARY}

Studies of adult neurogenesis have greatly expanded in the last decade, largely as a result of improved tools for detecting and quantifying neurogenesis. Occasions, in which original interpretations about neurogenesis have had to be reconsidered in light of subsequent reports indicate how careful attention to the strengths and limitations of detection and quantification methods are critical to substantiating study outcomes. Properly used and evaluated, the tools presently available to the research community provide ample resources to advance our understanding of the regulation of adult neurogenesis.

\section{ACKNOWLEDGMENTS}

We thank Drs. Juan Encinas and Grigori Enikolopov for permission to use previously unpublished images of their nestin-GFP and
nestin-CFPnuc mice, and Drs. Ludwig Aigner and Sebastien Couillard-Despres for permission to use previously unpublished images of doublecortin-GFP and doublecortin-dsRed mice.

\section{REFERENCES}

Ackman JB, Siddiqi F, Walikonis RS, LoTurco JJ. 2006. Fusion of microglia with pyramidal neurons after retroviral infection. J Neurosci 26: 11413-11422.

Alvarez-Buylla A, Seri B, Doetsch F. 2002. Identification of neural stem cells in the adult vertebrate brain. Brain Res Bull 57: 751-758.

Andreu Z, Khan MA, Gonzalez-Gomez P, Negueruela S, Hortiguela R, San Emeterio J, Ferron SR, Martinez G, Vidal A, Farinas I, et al. 2014. The cyclin-dependent kinase inhibitor p27 regulates radial stem cell quiescence and neurogenesis in the adult hippocampus. Stem Cells 33: $219-229$.

Baer K, Eriksson PS, Faull RL, Rees MI, Curtis MA. 2007. Sox-2 is expressed by glial and progenitor cells and Pax-6 is expressed by neuroblasts in the human subventricular zone. Exp Neurol 204: 828-831.

Barami K, Iversen K, Furneaux H, Goldman SA. 1995. Hu protein as an early marker of neuronal phenotypic differentiation by subependymal zone cells of the adult songbird forebrain. J Neurobiol 28: 82-101.

Bauer S, Patterson PH. 2005. The cell cycle-apoptosis connection revisited in the adult brain. J Cell Biol 171: 641650.

Bergmann O, Bhardwaj RD, Bernard S, Zdunek S, BarnabeHeider F, Walsh S, Zupicich J, Alkass K, Buchholz BA, Druid H, et al. 2009. Evidence for cardiomyocyte renewal in humans. Science 324: 98-102.

Bergmann O, Liebl J, Bernard S, Alkass K, Yeung MS, Steier P, Kutschera W, Johnson L, Landen M, Druid H, et al. 2012. The age of olfactory bulb neurons in humans. Neuron 74: 634-639.

Bernard S, Frisen J, Spalding KL. 2010. A mathematical model for the interpretation of nuclear bomb test derived ${ }^{14} \mathrm{C}$ incorporation in biological systems. Nucl Instrum Methods Phys Res B 268: 1295-1298.

Bhardwaj RD, Curtis MA, Spalding KL, Buchholz BA, Fink D, Björk-Eriksson T, Nordborg C, Gage F, Druid H, Eriksson PS, et al. 2006a. Neocortical neurogenesis in humans is restricted to development. Proc Natl Acad Sci 103: 12564-12568.

Bhardwaj RD, Curtis MA, Spalding KL, Buchholz BA, Fink D, Bjork-Eriksson T, Nordborg C, Gage FH, Druid H, Eriksson PS, et al. 2006b. Neocortical neurogenesis in humans is restricted to development. Proc Natl Acad Sci 103: $12564-12568$.

Bonfanti L. 2006. PSA-NCAM in mammalian structural plasticity and neurogenesis. Prog Neurobiol 80: 129-164.

Brown JP, Couillard-Despres S, Cooper-Kuhn CM, Winkler J, Aigner L, Kuhn HG. 2003. Transient expression of doublecortin during adult neurogenesis. J Comp Neurol 467: $1-10$.

Buck SB, Bradford J, Gee KR, Agnew BJ, Clarke ST, Salic A. 2008. Detection of S-phase cell cycle progression using 5- 
ethynyl- $2^{\prime}$-deoxyuridine incorporation with click chemistry, an alternative to using 5-bromo-2'-deoxyuridine antibodies. Biotechniques 44: 927-929.

Burns KA, Kuan CY. 2005. Low doses of bromo- and iododeoxyuridine produce near-saturation labeling of adult proliferative populations in the dentate gyrus. Eur J Neurosci 21: 803-807.

Busser J, Geldmacher DS, Herrup K. 1998. Ectopic cell cycle proteins predict the sites of neuronal cell death in Alzheimer's disease brain. J Neurosci 18: 2801-2807.

Cooper-Kuhn CM, Kuhn HG. 2002. Is it all DNA repair? Methodological considerations for detecting neurogenesis in the adult brain. Dev Brain Res 134: 13-21.

Couillard-Despres S, Winner B, Schaubeck S, Aigner R, Vroemen M, Weidner N, Bogdahn U, Winkler J, Kuhn HG, Aigner L. 2005. Doublecortin expression levels in adult brain reflect neurogenesis. Eur J Neurosci 21: 1-14.

DeCarolis NA, Mechanic M, Petrik D, Carlton A, Ables JL, Malhotra S, Bachoo R, Gotz M, Lagace DC, Eisch AJ. 2013. In vivo contribution of nestin- and GLAST-lineage cells to adult hippocampal neurogenesis. Hippocampus 23: 708-719.

Eisch AJ, Mandyam CD. 2004. Drug dependence and addiction. II: Adult neurogenesis and drug abuse. Am J Psychiatry 161: 426.

Eisch AJ, Mandyam CD. 2007. Adult neurogenesis: Can analysis of cell cycle proteins move us "Beyond BrdU"? Curr Pharm Biotechnol 8: 147-165.

Enikolopov G, Overstreet Wadiche L, Ge S. 2015. Transgenic and viral reporters and genetic analysis of adult neurogenesis. In Adult neurogenesis (ed. Gage FH, Kempermann G, Song H). Cold Spring Harbor Laboratory Press, Cold Spring Harbor, NY.

Ernst A, Alkass K, Bernard S, Salehpour M, Perl S, Tisdale J, Possnert G, Druid H, Frisen J. 2014. Neurogenesis in the striatum of the adult human brain. Cell 156: 1072-1083.

Grassi Zucconi G, Giuditta A. 2002. Is it only neurogenesis? Rev Neurosci 13: 375-382.

Hodge RD, Kowalczyk TD, Wolf SA, Encinas JM, Rippey C, Enikolopov G, Kempermann G, Hevner RF. 2008. Intermediate progenitors in adult hippocampal neurogenesis: Tbr2 expression and coordinate regulation of neuronal output. J Neurosci 28: 3707-3717.

Hodge RD, Nelson BR, Kahoud RJ, Yang R, Mussar KE, Reiner SL, Hevner RF. 2012. Tbr2 is essential for hippocampal lineage progression from neural stem cells to intermediate progenitors and neurons. J Neurosci 32: 6275-6287.

Kass L, Varayoud J, Ortega H, Munoz de Toro M, Luque EH. 2000. Detection of bromodeoxyuridine in formalin-fixed tissue. DNA denaturation following microwave or enzymatic digestion pretreatment is required. Eur J Histochem 44: 185-191.

Kempermann G, Jessberger S, Steiner B, Kronenberg G. 2004. Milestones of neuronal development in the adult hippocampus. Trends Neurosci 27: 447-452.

Komitova M, Eriksson P. 2004. Sox-2 is expressed by neural progenitors and astroglia in the adult rat brain. Neurosci Lett 369: 24-27.
Kornack DR, Rakic P. 2001. Cell proliferation without neurogenesis in adult primate neocortex. Science 294: 2127 2130.

Kowalczyk A, Filipkowski RK, Rylski M, Wilczynski GM, Konopacki FA, Jaworski J, Ciemerych MA, Sicinski P, Kaczmarek L. 2004. The critical role of cyclin D2 in adult neurogenesis. J Cell Biol 167: 209-213.

Kuan CY, Schloemer AJ, Lu A, Burns KA, Weng WL, Williams MT, Strauss KI, Vorhees CV, Flavell RA, Davis RJ, et al. 2004. Hypoxia-ischemia induces DNA synthesis without cell proliferation in dying neurons in adult rodent brain. J Neurosci 24: 10763-10772.

Lagace DC, Donovan MH, DeCarolis NA, Farnbauch LA, Malhotra S, Berton O, Nestler EJ, Krishnan V, Eisch AJ. 2010. Adult hippocampal neurogenesis is functionally important for stress-induced social avoidance. Proc Natl Acad Sci 107: 4436-4441.

Laplagne DA, Esposito MS, Piatti VC, Morgenstern NA, Zhao C, van Praag H, Gage FH, Schinder AF. 2006. Functional convergence of neurons generated in the developing and adult hippocampus. PLoS Biol 4: e409.

Malatesta P, Hartfuss E, Gotz M. 2000. Isolation of radial glial cells by fluorescent-activated cell sorting reveals a neuronal lineage. Development 127: 5253-5263.

Malatesta P, Hack MA, Hartfuss E, Kettenmann H, Klinkert W, Kirchhoff F, Gotz M. 2003. Neuronal or glial progeny: Regional differences in radial glia fate. Neuron 37: $751-$ 764.

Matsumoto Y, Tsunekawa Y, Nomura T, Suto F, Matsumata M, Tsuchiya S, Osumi N. 2011. Differential proliferation rhythm of neural progenitor and oligodendrocyte precursor cells in the young adult hippocampus. PLoS ONE 6: e27628.

Mullen RJ, Buck CR, Smith AM. 1992. NeuN, a neuronal specific nuclear protein in vertebrates. Development 116: 201-211.

Nacher J, Rosell DR, McEwen BS. 2000. Widespread expression of rat collapsin response-mediated protein 4 in the telencephalon and other areas of the adult rat central nervous system. J Comp Neurol 424: 628-639.

Nacher J, Crespo C, McEwen BS. 2001. Doublecortin expression in the adult rat telencephalon. Eur J Neurosci 14: 629-644.

Nacher J, Varea E, Blasco-Ibañez J, Castillo-Gomez E, Crespo C, Martinez-Guijarro F, Mcewen B. 2005. Expression of the transcription factor Pax6 in the adult rat dentate gyrus. J Neurosci Res 81: 753-761.

Nguyen L, Rigo JM, Malgrange B, Moonen G, Belachew S. 2003. Untangling the functional potential of PSANCAM-expressing cells in CNS development and brain repair strategies. Curr Med Chem 10: 2185-2196.

Nydal R, Lovseth K. 1965. Distribution of radiocarbon from nuclear tests. Nature 206: 1029-1031.

Patricio P, Mateus-Pinheiro A, Sousa N, Pinto L. 2013. Recycling paradigms: Cell cycle regulation in adult hippocampal neurogenesis and implications for depression. Mol Neurobiol 48: 84-96.

Peterson DA. 1999. Quantitative histology using confocal microscopy: Implementation of unbiased stereology procedures. Methods 18: 493-507. 
H.G. Kuhn et al.

Peterson DA. 2004. The use of fluorescent probes in cell counting procedures. In Quantitative methods in neuroscience-A neuroanatomical approach (ed. Evans SM, Janson AM, Nyengaard JR), pp. 85-114. Oxford University Press, Oxford.

Peterson DA. 2014. High-resolution estimation of multiple cell populations in tissue using confocal microscopy. In Fluorescence microscopy: Super-resolution and other novel techniques (ed. Conn M, Cornea A), pp. 171-184. Academic, Oxford.

Pleasure SJ, Collins AE, Lowenstein DH. 2000. Unique expression patterns of cell fate molecules delineate sequential stages of dentate gyrus development. J Neurosci 20: 6095-6105.

Rakic P. 2002. Adult neurogenesis in mammals: An identity crisis. J Neurosci 22: 614-618.

Rao MS, Shetty AK. 2004. Efficacy of doublecortin as a marker to analyse the absolute number and dendritic growth of newly generated neurons in the adult dentate gyrus. Eur J Neurosci 19: 234-246.

Schmitz C, Hof PR. 2005. Design-based stereology in neuroscience. Neuroscience 130: 813-831.

Seki T. 2002. Expression patterns of immature neuronal markers PSA-NCAM, CRMP-4 and NeuroD in the hippocampus of young adult and aged rodents. J Neurosci Res 70: $327-334$.

Spalding KL, Bhardwaj RD, Buchholz BA, Druid H, Frisen J. 2005. Retrospective birth dating of cells in humans. Cell 122: $133-143$.

Spalding KL, Arner E, Westermark PO, Bernard S, Buchholz BA, Bergmann O, Blomqvist L, Hoffstedt J, Naslund E, Britton T, et al. 2008. Dynamics of fat cell turnover in humans. Nature 453: 783-787.

Spalding KL, Bergmann O, Alkass K, Bernard S, Salehpour M, Huttner HB, Bostrom E, Westerlund I, Vial C, Buchholz BA, et al. 2013. Dynamics of hippocampal neurogenesis in adult humans. Cell 153: 1219-1227.
Stoykova A, Gruss P. 1994. Roles of Pax-genes in developing and adult brain as suggested by expression patterns. $J$ Neurosci 14: 1395-1412.

Thomas RM, Hotsenpiller G, Peterson D. 2007. Acute psychosocial stress reduces cell survival in adult hippocampal neurogenesis without altering proliferation. J Neurosci 27: 2734-2743.

van Praag H, Schinder AF, Christie BR, Toni N, Palmer TD, Gage FH. 2002. Functional neurogenesis in the adult hippocampus. Nature 415: 1030-1034.

Vega CJ, Peterson DA. 2005. Stem cell proliferative history in tissue revealed by temporal halogenated thymidine analog discrimination. Nat Methods 2: 167-169.

Vogel JS, Love AH. 2005. Quantitating isotopic molecular labels with accelerator mass spectrometry. Methods Enzymol 402: 402-422.

Winner B, Cooper-Kuhn C, Aigner R, Winkler J, Kuhn H. 2002. Long-term survival and cell death of newly generated neurons in the adult rat olfactory bulb. Eur J Neurosci 16: $1681-1689$.

Yang Y, Geldmacher DS, Herrup K. 2001. DNA replication precedes neuronal cell death in Alzheimer's disease. $J$ Neurosci 21: 2661-2668.

Yang CP, Gilley JA, Zhang G, Kernie SG. 2011. ApoE is required for maintenance of the dentate gyrus neural progenitor pool. Development 138: 4351-4362.

Zeng C, Pan F, Jones LA, Lim MM, Griffin EA, Sheline YI, Mintun MA, Holtzman DM, Mach RH. 2010. Evaluation of 5-ethynyl-2'-deoxyuridine staining as a sensitive and reliable method for studying cell proliferation in the adult nervous system. Brain Res 1319: 21-32.

Zhang RR, Cui QY, Murai K, Lim YC, Smith ZD, Jin S, Ye P, Rosa L, Lee YK, Wu HP, et al. 2013. Tet1 regulates adult hippocampal neurogenesis and cognition. Cell Stem Cell 13: $237-245$. 


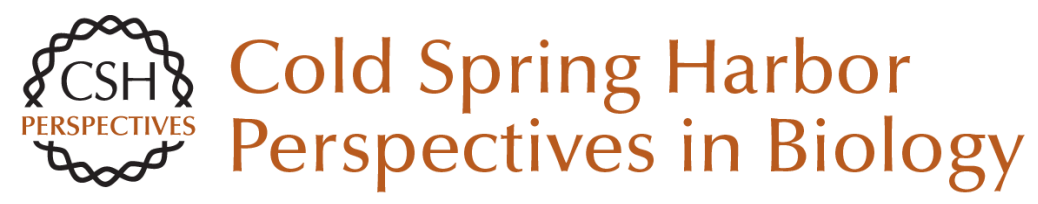

\section{Detection and Phenotypic Characterization of Adult Neurogenesis}

H. Georg Kuhn, Amelia J. Eisch, Kirsty Spalding and Daniel A. Peterson

Cold Spring Harb Perspect Biol 2016; doi: 10.1101/cshperspect.a025981

\section{Subject Collection Neurogenesis}

Adult Neurogenesis and Psychiatric Disorders Eunchai Kang, Zhexing Wen, Hongjun Song, et al.

Neuronal Circuitry Mechanisms Regulating Adult Mammalian Neurogenesis Juan Song, Reid H.J. Olsen, Jiaqi Sun, et al.

Neurogenesis in the Developing and Adult Brain

--Similarities and Key Differences Magdalena Götz, Masato Nakafuku and David Petrik

Genetics and Epigenetics in Adult Neurogenesis Jenny Hsieh and Xinyu Zhao

The Adult Ventricular-Subventricular Zone (V-SVZ) and Olfactory Bulb (OB) Neurogenesis Daniel A. Lim and Arturo Alvarez-Buylla

Diversity of Neural Precursors in the Adult Mammalian Brain Michael A. Bonaguidi, Ryan P. Stadel, Daniel A. Berg, et al.

Detection and Phenotypic Characterization of Adult Neurogenesis H. Georg Kuhn, Amelia J. Eisch, Kirsty Spalding, et al.

Maturation and Functional Integration of New Granule Cells into the Adult Hippocampus Nicolas Toni and Alejandro F. Schinder
Adult Olfactory Bulb Neurogenesis

Pierre-Marie Lledo and Matt Valley

Adult Neurogenesis in Fish Julia Ganz and Michael Brand

In Vitro Models for Neurogenesis Hassan Azari and Brent A. Reynolds

Engineering of Adult Neurogenesis and Gliogenesis

Benedikt Berninger and Sebastian Jessberger

Computational Modeling of Adult Neurogenesis James B. Aimone

Control of Adult Neurogenesis by Short-Range

Morphogenic-Signaling Molecules Youngshik Choe, Samuel J. Pleasure and Helena Mira

Adult Neurogenesis: An Evolutionary Perspective Gerd Kempermann

Epilepsy and Adult Neurogenesis

Sebastian Jessberger and Jack M. Parent

For additional articles in this collection, see http://cshperspectives.cshlp.org/cgi/collection/

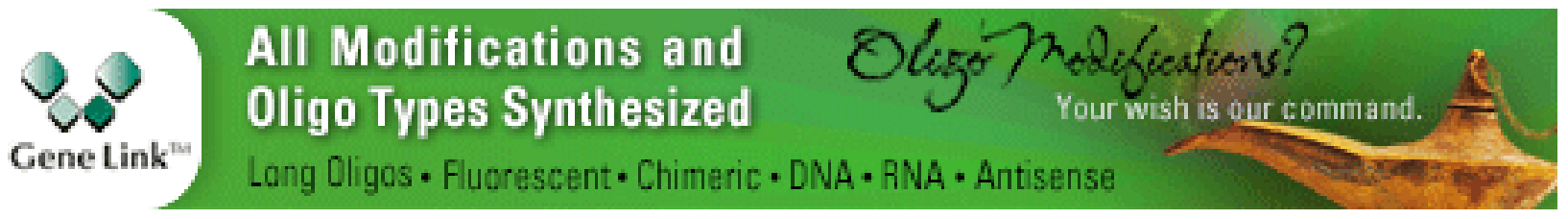

